\title{
Article \\ Conceptualizing Buddhisization: Malaysian Chinese Buddhists in Contemporary Malaysia
}

\author{
Lee Ooi Tan
}

check for updates

Citation: Tan, Lee Ooi. 2022. Conceptualizing Buddhisization: Malaysian Chinese Buddhists in Contemporary Malaysia. Religions 13: 102. https://doi.org/10.3390/ rel13020102

Academic Editor: Jack Meng-Tat Chia

Received: 9 December 2021

Accepted: 4 January 2022

Published: 21 January 2022

Publisher's Note: MDPI stays neutral with regard to jurisdictional claims in published maps and institutional affiliations.

Copyright: (c) 2022 by the author. Licensee MDPI, Basel, Switzerland. This article is an open access article distributed under the terms and conditions of the Creative Commons Attribution (CC BY) license (https:// creativecommons.org/licenses/by/ $4.0 /)$.
Department of Mass Communication, UOW Malaysia KDU Penang University College, George Town 10500, Penang, Malaysia; leeooi.tan@kdupg.edu.my

\begin{abstract}
This article conceptualizes the term "Buddhisization" to understand religious manifestations of Buddhist communities in contemporary Malaysia. By Buddhisization, I refer to a process of influencing or being influenced to be a Buddhist. The purpose of this conceptualization, apart from basic description and definition, is to outline some contexts for the use of Buddhisization and rationale behind the process. Drawing on in-depth interviews with Malaysian Chinese Buddhists, this study proposes six aspects of Buddhisization from the common experiences of Malaysian Chinese Buddhists. These aspects are the formalization of the taking refuge ceremony, participation in Buddhist associations, Buddhist examination, popularization of meditation courses, Buddhist weddings and Buddhist funerals. From experiences in Malaysia, this article suggests that the Buddhist minority context has enabled the process of being Buddhist at individual and institutional levels through initiatives and efforts of the Buddhist community. Urban educated middle-class Chinese Buddhists are inclined towards an acceptance of Buddhisization. As a consequence, it has complicated the journey of nation building in multi-religiosity Malaysia.
\end{abstract}

Keywords: Buddhisization; Malaysian Buddhism; maritime Buddhism; Chinese Buddhist

\section{Introduction: Conceptualizing Buddhisization}

The study of modernity and Buddhism has particularly taken a primary focus on religious transformations in the late nineteenth century. Furthermore, the discussion has predominantly examined Buddhist majority regions (Blackburn 2010; Bond 1992; Braun 2013; Caple 2020; Hansen 2007; Kemper 2015; Pittman 2001; Schober 2011; Scott 2020; Welch 1968). The conceptual formulation of Buddhist modernism has been constructed and emphasized from an internal dynamic of the religion and its larger interactions with society and politics. This article aims to discuss the term "Buddhisization" through an appraisal of the notion of Buddhist modernism. It focuses on the definition, concept, case study and condition of the Buddhisization of Chinese Buddhist community in contemporary Malaysia. I argue that the term Buddhisization entails a form of social interaction with common shared problem. Thus, this article is not a critique of modern Buddhism per se, but rather a critical reflection of its extension in understanding the multiplicities and forces at work of underlying expressions of modern Buddhism.

A total of $61.3 \%$ of the Malaysian population are Muslim and Islam is the official state religion. This followed by $19.8 \%$ of the population claiming to be Buddhist in the 2010 Census report. Additionally, 9.2\% of the population are Christian, while $6.3 \%$ are Hindus and others. Meanwhile, $83.6 \%$ of Malaysian Chinese claimed to be Buddhist. Religion is a form of identity politics in a racialization context in Malaysia. The issue of religious conversion constantly sparks political contestation as it is seen as a form of force assimilation by the non-Muslim population. The choice of the minority to strengthen its religion is to build identity through religion in facing dominant Islamization forces led by the state.

Buddhist modernism is a response of clerics as well as lay Buddhist elites to reinterpret the teaching of Buddhism with reference to modern Abrahamic religions which emphasize 
western monotheism, Romanticism, rationalism and scientific naturalism (McMahan 2008). It is a Pan-Asian phenomenon that happened concurrently in Buddhist majority countries from various Buddhist traditions since the nineteenth century within different social, cultural and political contexts. The phenomenon has influenced Buddhist minority countries through transnational connections and flows of ideas and resources. In McMahan's explanation of Buddhist modernism, he envisages multiplication of new traditions through international linkage beyond geographical and cultural boundaries (McMahan 2008). This analysis can be seen as an anticipation of new form of practice and certain way of modern Buddhism. Buddhisization is one of the new forms of the multiplication.

There are different expressions of Buddhist modernism in the Southeast Asian region. Anne Hansen (2007) suggests significance of Buddhist modernism in everyday modern life of ordinary folk from the case of Khmer Buddhists. The phenomenon of the Buddhist modernism has also profoundly entangled within a context of "nation-building in postcolonial Malaysia, Singapore and Indonesia" (Chia 2020, p. 4). Hence, the notion of Buddhisization in this study is situated within a context of nation-building and its relevance to the present life of Buddhist followers.

In this article, I define Buddhisization as the process of guiding someone or something under the influence of Buddhism. The person can be converted from a non-Buddhist or non-practicing Buddhist to a practicing Buddhist. It is a conceptual language to understand an attempt of the urban educated middle-class Buddhist community to shift towards more defined Buddhism and encourage an individual to become a more committed Buddhist through certain formalization of rituals and practices. This concept is a general explanation with a need to expand the scope of inquiry to greater geographical boundary and historical depth. This study focuses primarily on the experiences and observations of Chinese Buddhists in Malaysia.

The majority or minority context will significantly affect the manifestation of Buddhisization because of its structural nature and setting in different political contexts. It is therefore important to note that Buddhist communities in Malaysia, Indonesia and the Philippines belong to a minority context while Singapore is in the majority context. Even with the so-called minority context, Malaysia and Indonesia are different and multifaceted in many ways. Singapore also has its own complexity in the Buddhist majority context (Chia 2020, p. 2). In the Buddhist majority Singapore, Buddhism will probably enjoy official recognition through bureaucratization and institutionalization support by the state (Kuah-Pearce 2009). In contrast, the Buddhist minority community will take different path in the course of Buddhisization. Usually, the minority will be deprived of state-dominated institutional prerogative, but they undoubtedly enjoy certain level of religious freedom in terms of doctrinal standardization and tend to avoid direct intervention from a single powerful religious authority body (Lee and Ackerman 1997, p. 21). As a case of Buddhist minority context, the institutional level is basically in an informal setting and the rules are without power in legal enforcement. Even the Buddhist authority and bureaucratic establishment recognized by the Buddhist communities are always semi-official and can be easily challenged.

In addition, the religious competition between Buddhism and other world religions has profound consequences on the characteristics of Buddhisization. This is particularly true in learning of certain practices and rituals from other world religions. The Buddhist community has vibrant interactions with the other religious followers within a particular larger religious ecosystem in a country, which are sometimes beneficial but at times competitive. In the Malaysian context, the Islamization has intense consequences for non-Muslim religions. This article suggests that Buddhisization in Malaysia is indirectly a religious manifestation towards Islamization, as well as directly from an internal religious dynamic in order to strive for survival and growth in facing modernity. 


\section{Methodology and Sources}

The concept of Buddhisization was examined through two sets of data at the individual and institutional level. The data at the individual level were collected through in-depth interviews. The data set at institutional level were derived from a macro perspective by analyzing data collected from in-depth interviews and activities of three major Buddhist associations, namely the Malaysian Buddhist Association (MBA), Young Buddhist Association of Malaysia (YBAM) and Buddhist Tzu Chi Merits Society Malaysia (Tzu Chi). This study draws on their published and internal unpublished materials as sources to explore and obtain a macro view of Buddhisization in Malaysia.

A small sample size of nine interlocutors across gender, with four females and five males with ages ranging from 35 to 47 years old, was selected and in-depth interviews conducted to scrutinize the Buddhisization process of individual Buddhists. They were urban middle-class Mahayana Buddhists with three from a practicing Buddhist family, one highly influenced by a Taiwanese Buddhist group and the rest were from a traditional Chinese religious family. Informants selected are "active Buddhists" who have at least ten years of experiences in related Buddhist activities. The in-depth interview was designed to trace their commitment and development of personal Buddhist practice and understanding after many years of involvement in dharma learning. Interviews were conducted in the preferred language of interviewees and only related deliberative themes chosen to be transcribed and translated into English. All interviews were recorded or jotted with consent. To protect personal privacy and confidentiality, the identity of the interviewees was assigned with only alphabet: A, B, C and so on without explicitly referring to an individual's role or specific engagement with any Buddhist association. A total of nine Chinese Buddhists were involved in this study. There were three type of entry points where interviewees came across Buddhism: family, Buddhist association and individual. By entry point, I mean that the way in which they encountered Buddhism had constructed their religious perceptions and practices. Table 1 showed the list of interviewees and their entry point.

Table 1. List and breakdown of interviewees.

\begin{tabular}{cccc}
\hline Entry Point & Family & $\begin{array}{c}\text { Buddhist } \\
\text { Association }\end{array}$ & Individual \\
\hline $\mathrm{A}$ & $\mathrm{X}$ & & \\
\hline $\mathrm{B}$ & $\mathrm{X}$ & & \\
\hline $\mathrm{C}$ & $\mathrm{X}$ & $\mathrm{X}$ & \\
\hline $\mathrm{D}$ & & $\mathrm{X}$ & $\mathrm{X}$ \\
\hline $\mathrm{E}$ & & $\mathrm{X}$ & $\mathrm{X}$ \\
\hline $\mathrm{F}$ & & $\mathrm{X}$ \\
\hline $\mathrm{G}$ & & & \\
\hline $\mathrm{H}$ & & & \\
\hline $\mathrm{J}$ & & & \\
\hline
\end{tabular}

There were two major limitations in this sample selection. Firstly, the interviewees selected were educated with at least at diploma level and mostly with an undergraduate degree. Therefore, their opinions represented the common view of the higher-educated group in the Buddhist community in Malaysia. Secondly, they have encountered Buddhism with at least or more than ten years with or without taking refuge. Hence, they belonged to a stronger faith follower group in the Malaysian Buddhist community. Despite these two limitations, the interviews allowed me to explore the multifaceted issues surrounding the process of Buddhisization in contemporary Malaysia. 


\section{Buddhisizing Malaysian Chinese Buddhists}

There were six recurring themes from the interviews, namely, (i) taking refuge ceremony; (ii) Buddhist association; ${ }^{1}$ (iii) Buddhist examination; ${ }^{2}$ (iv) meditation; (v) Buddhist wedding and (vi) Buddhist funeral.

\subsection{Taking Refuge Ceremony}

Interviewees with an entry point through family and Buddhist association likely went through the taking refuge ceremony. All three interviewees with an entry point through family took the refuge ceremony at very young age with one by volunteer and another two by arrangement of parents. For them, the ceremony was a formal recognition of being a Buddhist. As Interviewee A shared with me, "the decision to have a stronger commitment to Buddhism by taking refuge ceremony was a natural process after many years of involvement in practicing and learning of Buddhism." Meanwhile, an intimate immersion with activity of association would create higher opportunity for Buddhists to participate in the ceremony:

After many years of engagement with a Buddhist society, I decided to make a stronger promise in continuing the religious practice even after graduation. In a dharma camp, the ambient was so religious and I totally surrender myself to Buddha. (Interviewee D).

The taking refuge ceremony was a pledge and it can be reinforced with a stronger commitment. Interviewee $\mathrm{F}$ revealed that due to participation in two different Buddhist associations, he had taken the pledge twice with two ceremonies conducted by two rectifiers as a reminder of his vow and also to show the commitment to his subsequent Buddhist work in social welfare. He joined a Buddhist association with a specific religious mission to benefit the society, and therefore decided to repeat the taking refuge ritual.

Three interviewees who learnt Buddhism through individual effort had a personal interpretation of the taking refuge ceremony. Three of them have not taken refuge. Interviewee $\mathrm{H}$ explained that "the most important thing was the practice of Buddha's teaching and the ceremony was just a ritual. If one already practiced what Buddha taught, he or she can be considered as a Buddhist without the need to go through a taking refuge ceremony." Interviewee J expounded that none of the Buddhist sutra specified the need for the ceremony. Their explanations demonstrate the flexible attitude of Buddhist in accepting or rejecting the ceremony and the decision was sometimes determined by personal justification.

\subsection{Buddhist Association}

All interviewees considered their experience and membership with at least one Buddhist association as an important aspect of the Buddhisization process. They engaged with one or more associations and their experiences became a major exposure in learning about Buddhist teachings and their faith in the religion consolidated throughout the years. Even for Interviewee $\mathrm{H}$, who studied Buddhism by individual effort, an association played a very important role.

An activity in a Buddhist association drew my attention on Buddha's teaching. Since then, I joined the activity every year by playing a role as participant, volunteer or donor ... I think the association was a crucial factor for me to get a better understanding about Buddhism. (Interviewee H).

For those who are committed in the religious work of a particular Buddhist association, it was a life mission. For example, Interviewee F expressed that the purpose of his life in this world is to help others and contribute to society. He was an active member of a Buddhist association that actively mobilizes volunteers to relieve suffering of the ill and poor people.

The other meaning to be active in a Buddhist association was for personal growth and meaning in life. Interviewee E participated in a local Buddhist association and joined all dharma talks in order to gain a deeper understanding of the philosophical teachings of the Buddha about impermanence so as to be free from attachment and suffering. E planned for a divorce after many years of marriage and sought the religion for potential growth 
in the new life. On the other hand, Interviewee $C$ enthusiastically led a dharma class in Buddhist association to cultivate new ideas for the younger generation and this created a more meaningful life besides work in company that overemphasized profit. Buddhist associations gave Buddhists a sense of purpose in life, and they were a fundamental factor for them to continue to learn the Dharma.

\subsection{Buddhist Examination}

The Buddhist examination was a common memory for interviewees who were raised in a family with Buddhist parents. The family arranged for them to learn dharma since their childhood, and this enabled them to appreciate any opportunity and recognition by taking and scoring in the exam. As elaborated by interviewee B,

My father regularly visited a temple nearby my house and he also wrote an essay for a writing competition organized by a national Buddhist association. I grew up with this background and attended dharma class since young. Hence, I took Buddhist examination at my primary school with a perfect score.

Those who were active in Buddhist associations also took the exam at some point in their life. Interviewee F registered for the exam during secondary school, whereas interviewee $\mathrm{D}$ and $\mathrm{E}$ did so in their undergraduate years. All of them willingly registered for the exam with encouragement from the Buddhist society they joined. The Buddhist society also provided an outline of the syllabus and a special revision plan during preparation for the exam at various levels.

In contrast, those who learnt Buddhism through individual determination were unlikely to consider the exam due to the lack of information or were not prepared for the comprehensive exam. For interviewees $\mathrm{H}$ and $\mathrm{J}$, they had never heard of the exam because they just focused on activities they preferred. Interviewee $G$ knew about the exam but had no interest to sit for the exam and considered reading more books as a better way to acquire Buddha's teachings.

\subsection{Meditation}

The practice of meditation was a privilege for all interviewees from three type of entry points. There were only particular interviewees who were fortunate enough to have opportunity and exposure to access the practice of meditation. The door of meditation was affected by personal preference and living conditions. Interviewee J was an enthusiast in meditation who attended many courses and learnt many methods.

I followed a meditation teacher in Taiping. He used a more flexible way ... I took opportunity whenever I was free to improve my level of meditation and join in various meditation courses even though I was an ordinary white-collar worker where sometimes might be quite busy. (Interviewee J)

An exposure to a related meditation course offered by a Buddhist camp was the key for practice as well. For interviewee E, the influence came from their university days where a special meditation course was implanted in an annual Buddhist camp. Similarly, interviewees A and F acquired meditation skills from Buddhist camps. However, three of them did not continue the practice.

On the other hand, a few interviewees expressed their missed opportunity or resistance to meditation practice. Interviewee $G$ did not have any experience with meditation. Another interviewee, $\mathrm{H}$, perceived participation in other types of Buddhist activities as sufficient to follow Buddha's path rather than meditation. Hence, it was obvious the practice of meditation depended on private inclination and acquaintance.

\subsection{Buddhist Wedding}

The choice of Buddhist wedding was a decision made by interviewees through mutual agreement with their spouses. From the explanation of interviewees, the wedding was blessed by a cleric and the venue was at a temple. The ceremony was arranged by their own 
expectations and there were different procedures for different wedding which included the choice of sutra, the duration and the food to serve.

I achieved consensus with my wife to organize a Buddhist wedding ... During the ROM [Registration of Marriage], a simple decoration set up in a temple I favored and a venerable was invited to conduct the wedding ceremony ... All decisions were made by my wife and me on how to create a memorable wedding in a Buddhist way. (Interviewee D)

The wedding was just the beginning of a long-term plan. Married couples aim to build a Buddhist family. As Interviewee D shared with me, after the wedding the couple determined to establish a Buddhist family by continuing to maintain certain practices such as chanting, attending dharma talk, practicing short meditation on daily basis and visiting a temple frequently. Interviewee A's experiences reaffirmed the intention of a Buddhist wedding:

I would expect a family with dharma learning and I would ensure my children to learn dharma as well ... This was easier for me as my husband was also a Buddhist. Hence, I would expect my life and family would continue the path. (Interviewee A)

\subsection{Buddhist Funeral}

The Buddhist funeral was commonly acknowledged as a better ritual option by interviewees from all three types of entry points in this research. One of the main reasons was the simplicity of the ritual arrangement. Interviewee A stated that the funeral accentuated an acceptance of a circle of life in the Buddhist teaching. One of my interviewees preferred the serenity of the funeral:

My father's funeral was conducted with so-called Buddhist funeral. It was a decision of my mother and me... The funeral was calm and peaceful without loud musical instruments ... I even arranged a special session like those in church to let relatives and friends to share their memories about my father... I was satisfied with the overall arrangement. (Interviewee G)

The Buddhist funeral can be arranged flexibly or with certain selected arrangements. Interviewee F, who was an active member in an association, explained that the Buddhist funeral was designed with certain procedures. Firstly, the funeral started with a Buddhist service for about twenty minutes with chanting (zhunian 助念) by members from the association to dedicate merits to the dead and console the living. Secondly, a cleric was invited to conduct the ritual and chant Buddhist sutra. Thirdly, members would attend to the deceased's family in order to listen to them and share their sadness.

There was concern about obtaining preapproval from parents as the older generation might still favor a traditional funeral. As stated by interviewee A, prior discussion and agreement were needed to avoid misunderstanding and to show respect to the dead as well as the living elders around.

The understanding on death among ordinary older generation of Malaysian Chinese was passé ... hence, there was a need to consult them on the funeral even though we preferred Buddhist way ... This agreement was also to deal with relatives who might have own opinion. (Interviewee A)

\section{Discussion}

Drawing on data collected from the in-depth interviews and supplemented with secondary data of three major Buddhist associations, MBA, YBAM and Tzu Chi, this section offers an overview of each aspect and analyzes the notion of Buddhisization.

\subsection{Formalization of Taking Refuge Ceremony}

The taking refuge ceremony is a widespread practice among Chinese Buddhists in Malaysia. MBA and YBAM's affiliated members have organized a substantial number of 
taking refuge ceremonies throughout the years. The ceremony is a simple initiation to officially rectify one to be a Buddhist. It is performed with a chanting session by a cleric, then the follower will pledge an acceptance of five precepts as a way of life and a dharma name will be assigned. This ceremony is to formalize the follower's Buddhist identity through a simple ritual.

The formalization of the taking refuge ceremony is a vital effort by Buddhist associations and clerics in Malaysia to ceremonially encourage Chinese Buddhists to be more committed in following the teaching of Buddha. There is a lack of past record on when the history of taking refuge ceremony started, but initiatives in conducting the taking refuge ceremony can be traced from activities initiated by an individual monk. Venerable Chuk Mor, commonly known as the "Father of Malaysian Chinese Buddhism," promoted the taking refuge ceremony. He considered the taking refuge ceremony an important part of his propagation activities with a mission to spread Buddhism for human life since the 1970s. Chuk Mor actively lectured and published on the doctrinal explanation on the benefit of taking refuge (Chia 2020, pp. 62-65). Many Mahayanist clerics have followed his footsteps in promoting the taking refuge ceremony. Buddhist associations also actively promote the ceremony, and the impact on the Buddhist community is significant.

This taking refuge ceremony is a religious pledge at a personal level, but beyond that it is a building of Buddhist community. After the ceremony, one might be more dedicated to practicing Buddhism by following the upright path of five precepts. At the same time, one formally and religiously belongs to the larger Buddhist community. With an increasing number of Chinese Buddhists deciding to adhere to this ceremony to obey the religious teaching in serious manner, it has contributed to the development of Buddhisization both at the individual and community levels. Statistically, the number of Buddhists has increased from 2000 to 2010 significantly (Tan 2020, p. 171).

\subsection{Participation in Buddhist Associations}

The total number and type of Buddhist associations in Malaysia are remarkable. Various Buddhist groups form their association by geographical location, religious tradition, education background or with social or religious missions (Tan 2020, pp. 180-87). Most associations belong to a geographical location type at the state, city or town level. Some associations are also organized by different Buddhist traditions ranging from Mahayana, Theravada, or Tibetan. There are variations within each tradition; for example, Theravada can originate from Sri Lanka, Thailand or Myanmar. For the category of education background, there is a substantial number of graduate youth groups in private as well public universities. The social- or religious-mission-related type is a group that seeks to promote certain forms of practices such as dharma class, meditation or charity-oriented practices.

The diverse Buddhist community in Malaysia represents the complexity of the religious practices and also the active associational life of the community. Similar to other maritime Southeast Asian countries where Buddhists are a religious minority, the sociocultural context has allowed an open setting for followers to practice any form of Buddhism either inherited locally or imported globally without a Buddhist authoritative entity with regulatory or bureaucratic power. Hence, involvement in associational activities is common among Buddhists in Malaysia. Most of the associations are officially registered with the Registrar of Society and there is a set of strict rules to run a religious association. For those who have leadership skills and are committed, they will play an active role in the management of association as an office bearer.

Besides those who take up a leadership role, ordinary members could participate in various activities organized by Buddhist associations. These activities span from basic prayer service or chanting sessions to charity, fundraising for the poor and those in disaster areas, seminars, recycling projects, et cetera. The level of participation and mobilization are noteworthy. For example, during the COVID-19 pandemic Buddhist associations in Malaysia have donated huge amount of healthcare-related products such as ventilators, personal protective equipment and hospital beds (Guang Ming Daily 2021; New Straits Times 2021). 
They also enthusiastically supported those who lost their jobs with direct financial aid as well as daily essential foods (Sin Chew Daily 2021). The charity work contributed by the Buddhist community - especially Tzu Chi一to disadvantaged groups and healthcare institutions during the pandemic is extraordinary. The organization has started a charity mission in Malaysia by following Taiwanese headquarters (Huang 2009). The active Chinese Buddhist associations have also influenced other Buddhist groups to follow their way of activities and practices (Samuels 2016).

The major Buddhist associations represent Buddhists' fight for political rights at both a countrywide and local level. They are pertinent political actors with a significant number of memberships and extensive activities in the eyes of authority, as well as other religious groups in the society. Some office bearers have likewise become opinion leaders who voice out concern on related issues for the community. A coalition of major Buddhist associations, the Malaysian Buddhist Consultative Council (MBCC), was formed and it represents the Buddhist community on relevant issues affecting the community (Malaysian Buddhist Consultative Council 2021). Hence, the associational life induces one to practice Buddhism and plays a role in defending Buddhists' political rights at a national level.

\subsection{Buddhist Examination}

The Buddhist examination is an important tool to inculcate knowledge through a formal assessment for Buddhists in Malaysia. This can lay down a foundation in understanding the teaching of Buddhism in a systematical way. Before the implementation of the examination, an ordinary follower who is born as a self-proclaimed Buddhist has less opportunity to genuinely comprehend the teachings of Buddhism. Many Chinese Buddhists used to go to the temple to perform religious prayers for merely personal fortune or protection without understanding the basic principles of the religion. The examination which targets various level of learners has profound influence on the Buddhisization of Malaysian Chinese.

The Buddhist examination started in 1973 and has developed throughout the years from basic to higher level to cater to the needs of different learners. "There are 4 levels of Buddhist examination, which are Preliminary (Beginner), Junior (Easy), Senior (Intermediate) and Higher (Advanced level)" (YBAM 2021). Many Buddhist societies in Malaysian secondary schools and universities encourage their members or students in the dharma class to register for the exam to test on personal grasp on Buddhist doctrine. Usually, the exam is organized in a school or association hall with a main test center in each state. Exam questions are set by a centralized committee. Even though the COVID-19 pandemic has unavoidably disrupted face to face exams, it has been carried out with an online exam since 2020. In 2021, the exam has gained recognition from the Ministry of Education, Malaysia, where students are now able to use these co-curriculum scores for public university admission (YBAM 2021).

\subsection{Popularization of Meditation Courses}

With the introduction of a meditation course by charismatic Buddhist teachers such as Venerable Chi Chern since the 1980s, it has become a major practice for some Buddhistsespecially those who have learned the meditation technique during their undergraduate study. Besides individual clerics, specific meditation centers such as Malaysian Buddhist Meditation Center ${ }^{3}$, Sati Meditation Centre, ${ }^{4}$ Santavana Forest Hermitage ${ }^{5}$ and Kechara Forest Retreat have also become popular with certain meditation methods. ${ }^{6}$ The meditation irrespective of any method or tradition is a good way to enhance one's understanding of Buddhism through tedious mind concentration practice. The practice will produce a believer with a stronger faith through mindful training process. It is a fundamental aspect to heighten the advancement of Buddhisization at the individual level.

The nature of openness in accepting various religious traditions has vigorously facilitated a wide spectrum of meditation methods and practices to flourish in Malaysia. Theravada, Mahayana and Tibetan Buddhist meditation methods have independently 
gained popularity in the country. Any new method imported can also easily be accepted by an existing religious community. For example, an Indian meditation movement established by Satya Narayan Goenka, who taught a specific method of Vipassana, also become popular among the Malaysian Buddhist community. The meditation camp is fully organized by volunteers through donation. The course has been designed by the headquarters from basic to advance level and practitioners can become a meditation teacher after achieving a higher level (Vipassana Meditation n.d.).

The influence of meditation on an individual will be stronger when one has integrated practice into one's daily live. There are Buddhists who do practice meditation on a daily basis but they are not the majority. For majority laypersons who have to build their career and family, the commitment of daily practice of meditation requires a strong vow. Some Buddhist associations and temples have planned for short meditation courses such as one-day events or even just an hour session to provide reminder or introductory course to devotees. The popularization of meditation has strengthened the practice of Buddhism at least at individual level; hence, it has contributed to Buddhisization at a societal level.

\subsection{Buddhist Wedding}

The Buddhist wedding is a contemporary creation promoted by some associations and prominent clerics since the 1990s in Malaysia. There is a lack of doctrinal reference to justify the need for a so-called Buddhist wedding. There is neither a standardized ceremony nor a specific arrangement. It is based on a simple notion of a couple who are Buddhists to perform a modest ritual with a blessing of Buddha and then they are religiously engaged. The arrangement of wedding agenda can be flexible and up to the couple to decide. Usually, it is completed in a Buddhist temple by inviting family members, relatives, colleagues and friends to witness an important moment in life. A cleric is invited to guide the chanting and blessing. The collective Buddhist wedding can be organized by a religious association as well. In 2019, Malaysian Buddhist Association jointly organized a mass wedding with the government during the Wesak Day celebration as a way to promote Buddhist weddings (The Star 2019).

The building of a Buddhist family is the next step after a wedding ceremony. The Buddhist family is an expectation by the married couple to practice Buddha's teaching in their daily lives. There is no standard arrangement for a so-called Buddhist family to follow; however, certain form of practices deemed Buddhistic are to be expected. These include adopting a vegetarian diet, chanting of sutra in the early morning, practicing of meditation, holding on teaching of Buddha in dealing with each other by following five precepts, or participating in Buddhist activities. The couple could decide what to follow because there is an absence of any religious authority who truly sets the rule for a Buddhist family. It is in a flexible setting and on individual choice in implementation.

The intention of Buddhist associations or clerics in promoting a Buddhist wedding and Buddhist family is for the continuation and proliferation of a community of faith. With the wedding blessed by a Buddhist cleric, the couple will then continue their life journey by following the path of Buddha (YBAM 2014). This is similar to other world religions that encourage followers to build a family committed to their faith. Therefore, I would suggest that the wedding is an imitation from other religions in order to allow Buddhists to build a family and spread the teaching of Buddha to the next generation. This is "entangled in the search for identity and cultural coherence, and in demands for social justice and political activity that have transformative consequences for the religion itself" (Dirlik 2003, p. 161 cited Nelson 2017, p. 19).

\subsection{Buddhist Funeral}

The Buddhist funeral has originated from a demand of Chinese society to reform the common practice of the luxurious and ceremonious traditional Chinese funeral. A document in the Penang Buddhist Association entitled By-Laws Relating to Funerals Rites and Ceremonies aimed to simplify the traditional Chinese funeral. It was an internal document 
for its members, formulated in 1927 (Francis 1974, Appendix III). The idea of a Buddhist funeral has continued to influence the Chinese Buddhist community in Malaysia. In the 1990s, there was a movement to reform certain cultural and religious practices of the Chinese community and the Buddhist group was part of the drive (Lau et al. 1998). Consequently, Buddhist representatives tried to advocate for a reform of Chinese funerals, motivating Buddhist groups and clerics to promote Buddhist funerals among the Chinese in Malaysia.

The Buddhist funeral is flexibly created without a standard set of religious doctrine. A common practice of the funeral usually fulfils these three basic criteria: vegetarian, Buddhist sutra and no burning of joss paper. Then it is fully a decision made by family members and the cleric on how to conduct it, which includes the food preparation, arrangement of ritual process and choice of Buddhist sutra. The flexibility has allowed family to cater to the preferences and different belief systems among its larger clan and kinship. In spite of this, the practice of no burning of joss paper money and house is frequently a touchy issue as traditional belief still perceives that as an essential item for the dead.

An association with a mission to address the issue of sickness, old age and death, called the Malaysian Buddhist Co-operative Society (MBCS), has started a more professional Buddhist funeral service in Klang Valley area. It provides various funeral plans just like an ordinary modern funeral service, from standard to premium packages (MBCS 2013). To cater to the need during pandemic, it has developed a special funeral for death caused by COVID-19 (MBCS 2021a). The association aims to "educate the public on how to have a simple, meaningful and dignified Buddhist funeral service for those who lost their loved ones" (MBCS 2021b). The association has published a book to introduce the concept of death and rebirth from a Buddhist's perspective together with its experiences and feedback (MBCS 2021c).

The decision to switch from a traditional Chinese funeral to Buddhist funeral is a choice influenced by three main factors. Firstly, being a Buddhist is a crucial factor as it is a matter of exposure to a Buddhist funeral. The promotion of the practice by Buddhist associations and clerics has affected Buddhists' decision to adopt a Buddhist funeral. Secondly, the funeral is simpler compared to a typical traditional Chinese funeral. Furthermore, the younger generation consider certain practices of a traditional funeral to be superstitious and unnecessary. The Buddhist funeral provides a ritual of healing from sadness through a calm and reflexive mode and allows participants to relate to the Buddha's teachings. Thirdly, the funeral is cost efficient. The overall cost of a Buddhist funeral is significantly lower after abandoning Chinese traditional practices such as burning of joss paper money and paper house, a longer ritual duration and an enormous amount of food for ritual offering.

\section{Conclusions}

This article has demonstrated how one's learning path is imperative to the Buddhisization process of an individual Buddhist in contemporary Malaysia. As demonstrated by the study, whether an individual was born in a Buddhist family, joined a Buddhist association or initiated by individual effort has a different level of influence on various aspects of Buddhisization. In general, those Buddhists who are raised by Buddhist parents will have a stronger commitment to their faith in future life whereas those who have contacted Buddhism through association or by individual exhibit different aspects of Buddhisization. Nonetheless, in all these three types their decision making and preference of the six aspects of Buddhisization depend on a number of factors, including the nature of the activity they join, fellow Buddhists they meet and their educational and career background. At the individual level, personal circumstances are directly the main reason and justification for the need of the religious faith. This is similar to Nelson's (2013) study of experimental Buddhism in Japan, which he highlights the multiple factors in evaluating the religion based on an individual's judgement for their own benefit.

The Buddhisization in Malaysia has indirectly formalized in six aspects at an institutional level for followers to practice Buddhism without a state-dominated bureaucracy. 
These six aspects of Buddhisization are, namely, formalization of the taking refuge ceremony, participation in Buddhist associations, Buddhist examination, popularization of meditation courses, Buddhist weddings and Buddhist funerals. Although the Buddhisization process is casual in nature, it is crucial to institute a certain level of formality with authority recognized by the religious community from national Buddhist associations, especially YBAM and MBA. The discussion section has presented an overview of its role in the process of creating the influence of Buddhism on followers in a more defined mode.

The minority or majority context has an impact on the characteristics of Buddhisization. In comparison, there are similarities as well as differences compared to the case of Singapore on the matter of being Buddhist. Charity work, as well as an attempt to seek rationalization of religious practices, is similar for Chinese Buddhists in Malaysia and Singapore. However, as a Buddhist-majority country, Singapore has inevitably taken a path of state-dominated and -influenced religious engineering which bureaucratized an ethnoreligious law framework and entrenched political rhetoric of Asian values in the nation's city (Kuah-Pearce 2009). In addition, Chinese Buddhists in Singapore also face aggressive religious competition from evangelical Christianity (Kuah-Pearce 2009, pp. 279-89). In contrast, Chinese Buddhists in Malaysia have been relentlessly shrouded by a dominant state religion that enjoyed complete institutional and financial support. Nevertheless, the context of being both an ethnic and religious minority has shown a lack of restrictions in religious doctrine, a self-reliance path of growth and self-rule that is determined by contribution and negotiation of various Buddhist traditions and associations.

The Buddhisization in Malaysia is also a form of community building of Chinese Buddhists within a nation that is dominated by a Muslim majority. The community building has constructed a distinctive Buddhist identity that shared amongst the Chinese community who claimed to be a Buddhist even with diverse practices in traditional Chinese religions and different traditions of Buddhism. It happened in a "quiet" way in the early stage in the 1980s, as observed by Ling (1992). Since the 1990s, the process has intensified with formalization of religious institution and identity formation. With this reorientation of religious practices as well as institutionalization of religious spheres outside the state authority domain, it has further planted the underpinning of politicization of the Chinese community, where the ethnicity politics are now convoluted with a dimension of religiosity. This has inevitably complicated the political contestation between Muslims and nonMuslims in contemporary Malaysia. The formation of a Buddhist community and identity will impact political contestation of various religious groups, especially between Muslims and Buddhists. The official state-dominated Islamization policies will further trigger this aspect of politicization and its resistance. Future studies will have to look into this aspect of contestation and its implication for the nation building in Malaysia.

Funding: This research received no external funding.

Institutional Review Board Statement: Ethical review and approval were waived for this study due to full anonymity and non-medical study.

Informed Consent Statement: Informed consent was obtained from all subjects involved in the study.

Conflicts of Interest: The author declares no conflict of interest.

\section{Notes}

1 Buddhist association in the data and discussion section referred to all Buddhist groups registered with the Registrar of Society (ROS) in general and not limited to a few major national Buddhist associations. Monasteries or temples registered with ROS were also part of the categorization.

2 Buddhist examination mentioned also from any exam arranged by various Buddhist groups but not solely from the formal exam by the Malaysian Buddhist Association. There were differences among three type of interviewees who encountered Buddhism in various ways in terms of the nature of activities they joined and how they perceived certain Buddhist practices.

https:/ / www.mbmcmalaysia.org/p/about-mbmc.html (accessed 7 July 2021).

http:/ / www.sati-meditation.org/ (accessed 7 July 2021). 
https:/ / santavana.org/ (accessed 7 July 2021).

https:/ /www.kecharaforestretreat.com/ (accessed 7 July 2021).

\section{References}

Blackburn, Anne M. 2010. Locations of Buddhism: Colonialism and Modernity in Sri Lanka. Chicago: University of Chicago Press.

Bond, George D. 1992. The Buddhist Revival in Sri Lanka: Religious Tradition, Reinterpretation, and Response. Delhi: Motilal Banarsidass.

Braun, Erik. 2013. The Birth of Insight: Meditation, Modern Buddhism, and the Burmese Monk Ledi Sayadaw. Chicago: University of Chicago Press.

Caple, Jane E. 2020. Morality and Monastic Revival in Post-Mao Tibet. Honolulu: University of Hawaii Press.

Chia, Jack Meng-Tat. 2020. Monks in Motion: Buddhism and Modernity across the South China Sea. New York: Oxford University Press.

Dirlik, Arif. 2003. Modernity in Question? Culture and Religion in an Age of Global Modernity. Diaspora 12: 147-70.

Francis, Michael S. 1974. The Penang Buddhist Association: A Historical Outline 1925-1965. Unpublished honours thesis, School of Humanities, Universiti Sains Malaysia, George Town, Malaysia.

Guang Ming Daily. 2021. YBAM fund raising campaign for Hospital Kangar. Guang Ming Daily, July 13.

Hansen, Anne R. 2007. How to Behave: Buddhism and Modernity in colonial Cambodia 1860-1930. Honolulu: University of Hawai'i Press. Huang, Julie C. 2009. Charisma and Compassion: Cheng Yen and the Buddhist Tzu Chi Movement. Cambridge: Harvard University Press.

Kemper, Steven. 2015. Rescued from the Nation: Anagarika Dharmapala and the Buddhist World. Chicago: University of Chicago Press.

Kuah-Pearce, Khun Eng. 2009. State, Society, and Religious Engineering: Towards a Reformist Buddhism in Singapore. Singapore: Institute of Southeast Asian Studies.

Lau, Pan Shi, Guan Fu Lai, and Zhang Yi Lv. 1998. Malaysian Chinese Thought Reformation Convention: An Essay Collection. Kuala Lumpur: Gabungan Pertubuhan Cina Malaysia.

Lee, Raymond L. M., and Susan A. Ackerman. 1997. Sacred Tensions: Modernity and Religious Transformation in Malaysia. Columbia: University of South Carolina Press.

Ling, Trevor O. 1992. Revival without Revivalism: The Case of the Buddhists in Malaysia. Sojourn: Social Issues in Southeast Asia 7: 326-35. [CrossRef]

Malaysian Buddhist Consultative Council. 2021. Press Statement by Malaysian Buddhist Consultative Council (MBCC). Available online: https:/ / www.facebook.com/mybuddhistcc/photos/a.1870189539676822/4938085329553879/ (accessed on 13 September 2021).

MBCS. 2013. Business Segments-Funeral Services. Available online: https:/ / www.mbcs.org.my/funeral-details.php?ID=2\&list=items (accessed on 13 September 2021).

MBCS. 2021a. MBCS Covid19 Funeral Package. Available online: https:/ / www.mbcs.org.my/funeral-details.php?ID=8\&list=items (accessed on 13 September 2021).

MBCS. 2021b. Funeral Publications. Available online: https:/ / www.mbcs.org.my/funeral-details.php?ID=4\&list=items (accessed on 13 September 2021).

MBCS. 2021c. A Buddhist Concept of Rebirth. Klang: MBCS.

McMahan, David L. 2008. The Making of Buddhist Modernism. New York: Oxford University Press.

Nelson, John. 2013. Experimental Buddhism: Innovation and Activism in Contemporary Japan. Honolulu: University of Hawai'i Press.

Nelson, John. 2017. Diasporic and Convert Communities in Buddhisms around the Globe. In Handbook of Contemporary Buddhism. Edited by Michael Jerryson. London and New York: Oxford.

New Straits Times. 2021. First non-governmental organisation PPV under NIP begins operation. New Straits Times, June 19.

Pittman, Don A. 2001. Toward a Modern Chinese Buddhism: Taixu's Reforms. Honolulu: University of Hawaii Press.

Samuels, Jeffrey. 2016. Buddhist Disaster Relief: Monks, Networks, and the Politics of Religion. Asian Ethnology 75: 53-74. [CrossRef]

Schober, Juliane. 2011. Modern Buddhist Conjunctures in Myanmar: Cultural Narratives, Colonial Legacies, and Civil Society. Honolulu: University of Hawai'i Press.

Scott, Gregory A. 2020. Building the Buddhist Revival: Reconstructing Monasteries in Modern China. New York: Oxford University Press. Sin Chew Daily. 2021. Yayasan Sin Chew, FGS contribute to welfare centers. Sin Chew Daily, May 18.

Tan, Lee Ooi. 2020. Buddhist Revitalization and Chinese Religions in Malaysia. Amsterdam: Amsterdam University Press.

The Star. 2019. Glimpses into Buddhist way of life. The Star Metro News, May 2. Available online: https://www.thestar.com.my/ metro/metro-news / 2019/05/02/glimpses-into-buddhist-way-of-life/?fbclid=IwAR2zV8gUKOHh81nkvTvU9TQcEhuv7T3 HyzWH6Ml1NPnKRwnlrBstyAhgtZA(accessed on 10 July 2021).

Vipassana Meditation. n.d. Official Website. Available online: https://www.dhamma.org/en/about/goenka (accessed on 10 June 2021). Welch, Holmes. 1968. The Buddhist Revival in China. Cambridge: Harvard University Press.

YBAM. 2014. YBAM 2014 Seminar on Buddhist Parenting. Berita YBAM 135: 13-19.

YBAM. 2021. Available online: https:/ / www.facebook.com/YBAMalaysia/photos/a.169672373677/10159712833378678/ (accessed on 30 July 2021). 